\title{
8. NEOGENE DINOFLAGELLATE CYST BIOSTRATIGRAPHY FROM SITES 815 AND 823, LEG 133, NORTHEASTERN AUSTRALIAN MARGIN ${ }^{1}$
}

\author{
Andrew McMinn ${ }^{2}$
}

\begin{abstract}
Well-preserved and diverse dinoflagellate cyst assemblages were recovered from Ocean Drilling Program (ODP) Sites 815 and 823. The late middle Miocene is indicated by the presence of Sumatradinium spp. up to Core 133-823C-10R at Site 823 and up to Core 133-815B-47X at Site 815. Melitasphaeridium choanophorum appeared in the late Miocene (Cores 133-823C-19R and 133-815B-45X) and disappeared during the late Pliocene (Cores 133-823C-56X and 133-815 B-4H). Other significant biostratigraphic datums include the disappearances of Hystrichokolpoma rigaudiae (Cores 133-823B-22X and 133-815A-5H) and Dapsilidinium pasteilsii (Cores 133-823B-23X and 133-815A-5H) at the end of the Pliocene; the first appearance of Blysmatodinium argoi during the late Miocene (Core 133-815B-43X) and subsequent disappearance during the early Pliocene (Cores 133-823B-47X and $-815 \mathrm{~B}-27 \mathrm{X}$ ); and the disappearance of Operculodinium longispinigerum (Sections 133-823A-3H-4 and -815A-1H-3) during the Pleistocene. These results are consistent with the ages determined by nannoplankton and foraminifers at these sites and also with the dinoflagellate biostratigraphy from Leg 123 (McMinn, 1992).

The Neogene assemblages of both sites are characterized by abundant Spiniferites spp., Impagidinium spp., and Operculodinium spp. Both Tuberculodinium vancampoae and Lingulodinium machaerophorum are consistently present and sometimes abundant but most other species occur only sporadically. Peridiniaceae, which is often associated with nutrient enrichment, is rare in all samples. This suggests that the environment has always been oligotrophic. Impagidinium spp., taxa typically associated with oceanic environments, are present throughout both cores, but are more abundant in post-Pliocene sediments.
\end{abstract}

\section{INTRODUCTION}

Site 815 is located on the northern margin of the Marion Plateau, approximately $250 \mathrm{~km}$ east of the Australian mainland (Fig. 1). This site was drilled in $450 \mathrm{~m}$ of water and contains a Pleistocene to middle Miocene sequence. Six lithostratigraphic units were recognized and these are (Unit I) Pleistocene to early late Pliocene age sequence of foraminifer nannofossil to nannofossil foraminifer ooze, (Unit II) early Pliocene age nannofossil ooze and unlithifed nannofossil mixed sediment, (Unit III) early Pliocene age chalk and lithified mixed sediment, (Unit IV) late late Miocene age foraminifer nannofossil and nannofossil foraminifer chalk, (Unit V) late middle to late Miocene age calcareous to dolomitized foraminifer packstone, and (Unit VI) latest early to early middle Miocene age dolomitized benthic foraminifer rudestone to floatstone (Davies, McKenzie, Palmer-Julson et al., 1991).

Site 823 is located in the central-western Queensland Trough (Fig. 1), in $1638 \mathrm{~m}$ of water and was drilled to a depth of $1011 \mathrm{~m}$. The Pleistocene to late middle Miocene sequence consists of seven stratigraphic units: (Unit I) Pleistocene age nannofossil ooze interbedded with debris flows and turbidites; (Unit II) Pleistocene to late Pliocene age nannofossil ooze interbedded with debris flows and turbidites; (Unit III) early Pliocene age nannofossil ooze interbedded with debris flows and turbidites; (Unit IV) early Pliocene to latest late Miocene age foraminifer nannofossil chalk and is characterized by larger slump features (compared to III); (Unit V) late Miocene age nannofossil mixed sediment to nannofossil claystone; (Unit VI) late Miocene age bioturbated nannofossil chalk to mixed sediment; (Unit VII) late Miocene to late middle Miocene age lithoclastic rudstone with shallow-water, platform-derived pebbles and clasts (Davies, McKenzie, Palmer-Julson et al., 1991).

\footnotetext{
'McKenzie, J.A., Davies, P.J., Palmer-Julson, A., et al., 1993. Proc. ODP, Sci. Results, 133: College Station, TX (Ocean Drilling Program).

${ }^{2}$ Antarctic Co-operative Research Centre and Institute of Antarctic and Southern Ocean Studies, University of Tasmania, Box 252C, Hobart 7001, Australia.
}

Comparatively few studies of Neogene dinoflagellate cysts have been done and most of these are of Northern Hemisphere, temperate and boreal assemblages. A summary of previously published Northern Hemisphere Neogene dinoflagellate data is presented in Head et al. (1989). Published accounts of Neogene assemblages from the Southern Hemisphere are limited to those of Deflandre and Cookson (1955), Truswell et al.(1985), Martin (1991) and McMinn (1992a) from Australia, and Gamerro and Archangelsky (1981) from Argentina. Similarly, there have been few published studies of Neogene tropical dinoflagellate cyst assemblages. These include the studies by Jarvis and Tocher (1985) of equatorial Pacific Ocean core samples and McMinn (1992a) from the eastern Indian Ocean. However, subtropical assemblages from the Gulf of Mexico (Duffield and Stein [1986], Lenoir and Hart [1986], and Wrenn and Kokinos [1986]), are similar to the tropical assemblages reported by McMinn (1992a).

\section{MATERIALS AND METHODS}

Thirty-eight, $10 \mathrm{~cm}^{3}$ samples from Site 815 and 47 from Site 823 were collected for this study by Leg 133 shipboard scientists and were processed at the Palynological Laboratory of the New South Wales (N.S.W) Geological Survey. Samples were initially disaggregated in $30 \% \mathrm{HCl}$ and then left overnight in $30 \% \mathrm{HF}$. After repeated washings in distilled water they were sieved on an $8 \mu \mathrm{m}$ screen with the aid of an ultrasonic needle. The residue was then further concentrated by the use of a heavy liquid $\mathrm{ZnBr}_{2}$ solution having a 2.1 specific gravity. No oxidation was used in sample preparation. Residues were mounted in Eukitt and are stored in the Palaeoecology Collection of the Institute of Antarctic and Southern Ocean Studies at the University of Tasmania, Hobart. All photography was done with a Zeiss Photomicroscope II at the N.S.W. Geological Survey, Sydney. All specimens on a measured slide were counted to obtain the number of cysts/g of sediment; if this number was less 400 , an additional slide was examined. The "relative abundance" was based on a count of 200 palynomorphs and represents the number of dinoflagellate cysts in a palynomorph assemblage. Percentage distributional data are documented in Tables 1 and 2 . 


\section{BIOSTRATIGRAPHY}

Because no widely accepted Neogene dinoflagellate zonation is currently available, the dinoflagellate cyst assemblages will be discussed with reference to age determinations based on foraminifers and nannofossils (Davies, McKenzie, Palmer-Julson, et al., 1991).

\section{Middle Miocene}

A single late middle Miocene age sample (133-823C-24R-3, 22$24 \mathrm{~cm}$ ) was examined; this was characterized by abundant Lingulodinium machaerophorum, Operculodinium israelianum, and Spiniferites bulloideus. Although the sample contained abundant specimens, species diversity was low and no biostratigraphically significant species were present.

\section{Late Miocene}

Late Miocene age assemblages were examined from Samples $133-815 B-47 X-3,100-103 \mathrm{~cm}$, through $-43 X-3,87-93 \mathrm{~cm}$, and $133-$ $823 \mathrm{C}-21 \mathrm{R}-4,50-53 \mathrm{~cm}$, through $-823 \mathrm{~B}-70 \mathrm{X}-4,60-64 \mathrm{~cm}$. Assemblages typically are dominated by Spiniferites bulloideus with common Lingulodinium machaerophorum, Operculodinium israeliamum, Spiniferites hyperacanthus, and Tuberculodinium vancampoae. Intermittently common forms include Batiacasphaera spp., Impagidinium patulum, Operculodinium longispinigerum, and Operculodinium echigoense. Significant first appearances include Blysmatodinium argoi, Dapsilidinium pasteilsii, and Melitasphaeridium choanophorum. Significant last occurrences include Sumatradinium hispidum.

\section{Early Pliocene}

Early Pliocene age sequences occur from Samples 133-823B-68X$4,65-68 \mathrm{~cm}$, to $-40 \mathrm{X}-4,66-79 \mathrm{~cm}$, at Site 823 and from Samples $133-815 \mathrm{~B}-26 \mathrm{X}-3,98-103 \mathrm{~cm}$, to $-41 \mathrm{X}-3,87-93 \mathrm{~cm}$, and $133-815 \mathrm{~A}-$ $9 \mathrm{H}-3,87-89 \mathrm{~cm}$, through $-24 \mathrm{H}-3,100-105 \mathrm{~cm}$, at Site 815 . Spiniferites bulloideus is the most abundant species in the majority of samples, although Batiacasphaera spp., Dapsilidinium pasteilsii, Hystrichokolpoma rigaudiae, Impagidinium paradoxum, Impagidinium patulum, Lingulodinium machaerophorum, Melitasphaeridium choanophorum, Operculodinium longispinigerum, Operculodinium echigoense, and Tuberculodinium vancampoae are also sometimes abundant. No significant first appearances are seen in the early Pliocene although Batiacasphaera spp., Blysmatodinium argoi, and Spiniferites pachydermus disappear.

\section{Late Pliocene}

Late Pliocene age assemblages occur in samples from 133-823A$22 \mathrm{X}-4,60-64 \mathrm{~cm}$, to $-38 \mathrm{X}-4,66-70 \mathrm{~cm}$, and $133-815 \mathrm{~A}-3 \mathrm{H}-3,105-$ $109 \mathrm{~cm}$, through $-8 \mathrm{H}-3,93-97 \mathrm{~cm}$. The most abundant species are Melitasphaeridium choanophorum, Operculodinium longispinigerum, and Spiniferites ramosus. Other spasmodically common taxa include Dapsilidinium pasteilsii, Impagidinium aculeatum, Impagidinium paradoxum, Impagidinium patulum, Impagidinium sp., Operculodinium centrocarpum, Operculodinium israelianum, Spiniferites bulloideus, and Spiniferites hyperacanthus. No significant first appearances occur but important disappearances include Dapsilidinium pasteilsii, Hystrichokolpoma rigaudiae, and Melitasphaeridium choanophorum.

\section{Quaternary}

Quaternary age assemblages were obtained from Samples 133$823 \mathrm{~A}-1 \mathrm{H}-4,65-69 \mathrm{~cm}$, through $-11 \mathrm{H}-4,65-69 \mathrm{~cm}, 133-823 \mathrm{~B}-13 \mathrm{X}-3$, $58-60 \mathrm{~cm}$, through $-16 \mathrm{X}-3,60-64 \mathrm{~cm}$, and $133-815 \mathrm{~A}-1 \mathrm{H}-3,121-125$ $\mathrm{cm}$, through $-2 \mathrm{H}-3,121-125 \mathrm{~cm}$. These assemblages are characterized

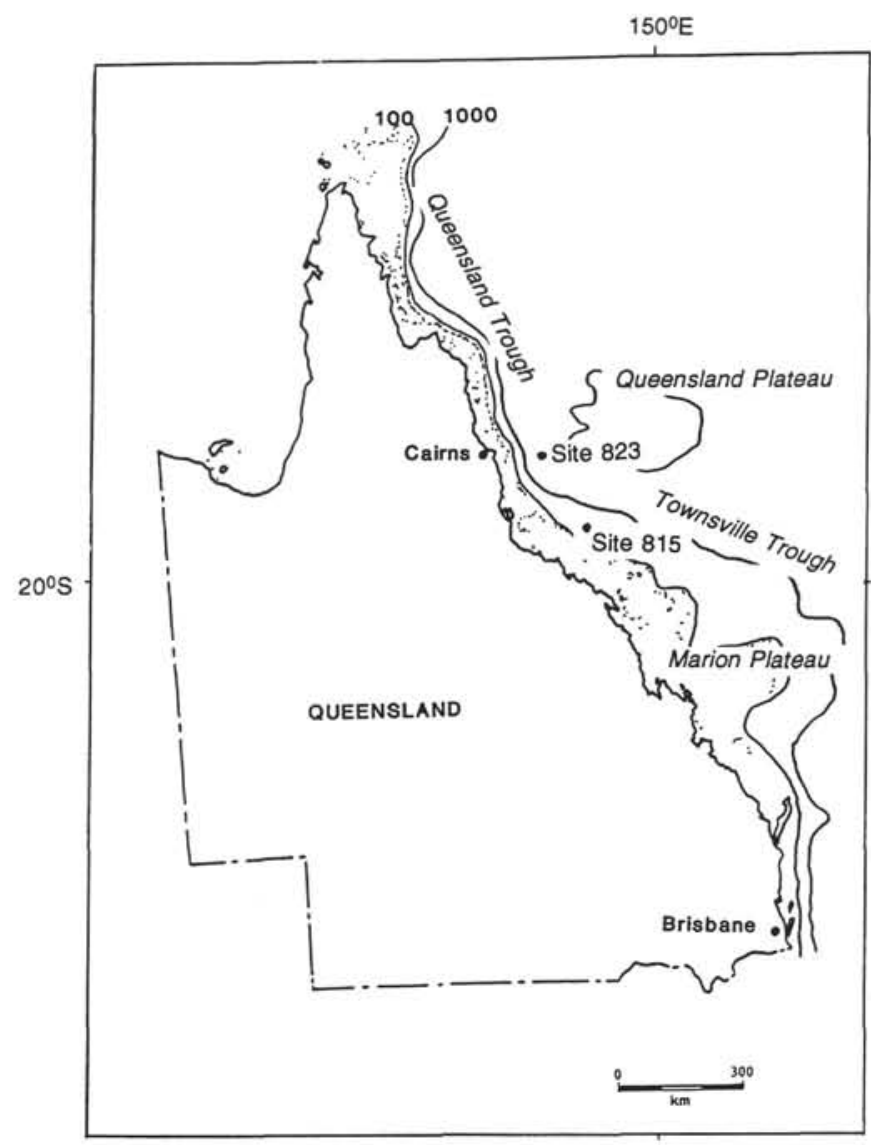

Figure 1. Location of Sites 815 and 823. Bathymetry in meters.

by abundant Impagidinium aculeatum, Impagidinium paradoxum, and Spiniferites bulloideus. Other common forms include Achomosphaera sp., Impagidinium patulum, Impagidinium sphaericum, Impagidinium strialatum, Lingulodinium machaerophorum, Operclodinium centrocarpum, Operculodinium israelianum, Spiniferites hyperacanthus, Spiniferites ramosus, and Tuberculodinium vancampoae. The only significant biostratigraphic event within the Quaternary sequence is the disappearance of Operculodinium longispinigerum.

Most of the significant biostratigraphic datums documented by McMinn (1992a) from the Argo Abyssal Plain in the Indian Ocean off northwestern Australia occur synchronously at Sites 815 and 823, off northeastern Australia. Of those datums identified as biostratigraphically significant by McMinn (1992a) from northwestern Australia, only the middle Miocene disappearance of Systematophora placacantha is absent. Sumatradinium hispidum, however, disappears in the late Miocene sequences of Sites 815 and 823 of northeastern Australia, but is absent from similarly aged samples from northwestern Australia.

Blysmatodinium argoi appears in the late Miocene section and disappears in the early Pliocene sections of both northeastern and northwestern Australia. Melitasphaeridium choanophorum similarly appears simultaneously in both northeastern and northwestern Australia in the late Miocene sequence and disappears synchronously in the late Pliocene section. Both Dapsilidinium pasteilsii and Hystrichokolpoma rigaudiae appear earlier in the Tertiary, but disappear in the late Pliocene age sections of Sites 815 and 823 ; neither species is present in the Quaternary sequence of Site 820 (McMinn, this volume). Their later disappearance in the Pleistocene section of northwestern Australia is likely to be the result of reworking from the turbidite sequence of Site 765 (McMinn, 1992a). 
Table 1. Percentage distribution of dinoflagellate taxa at Site 815 .

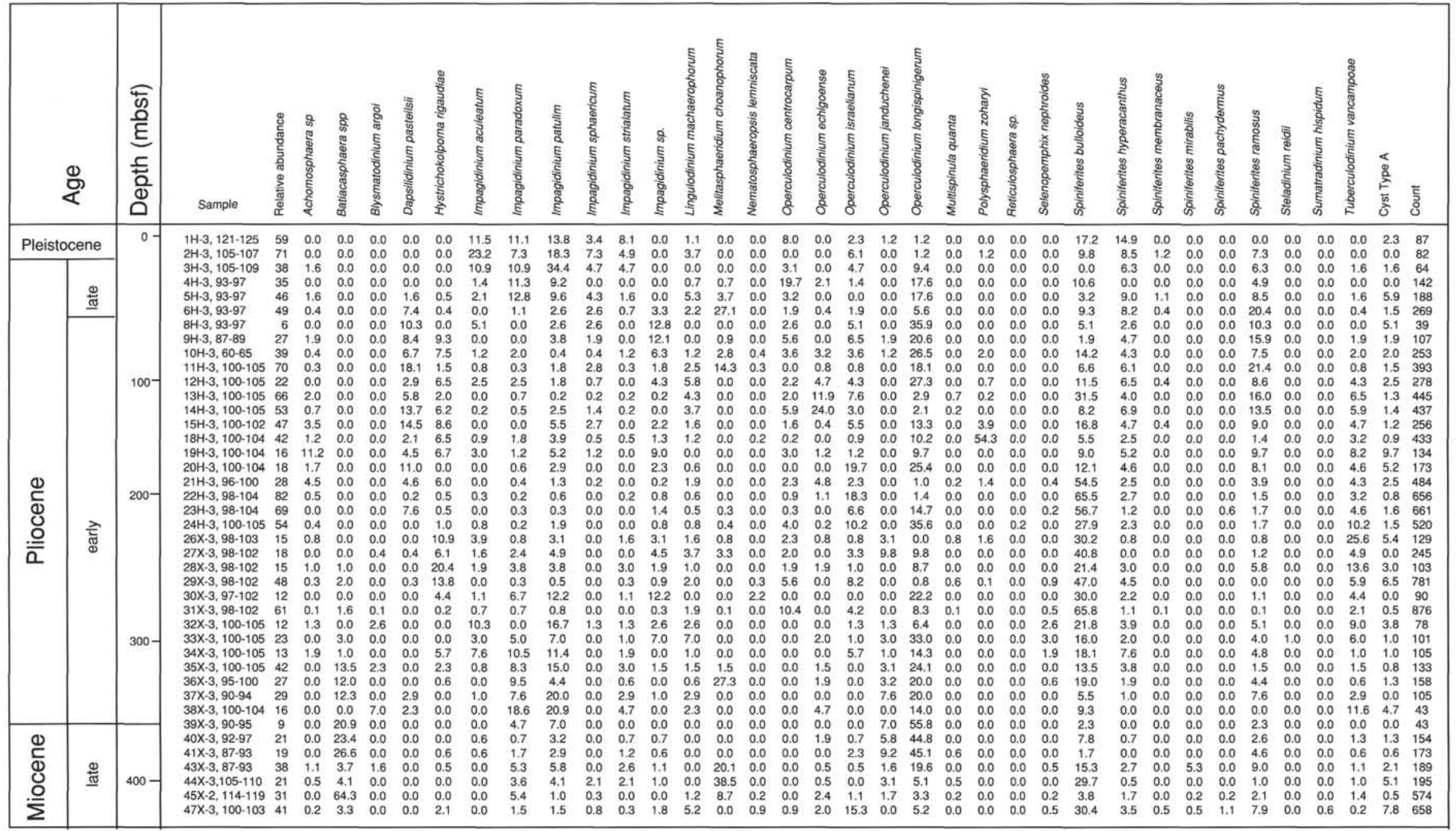


Table 2. Percentage distribution of dinoflagellate taxa at Site $\mathbf{8 2 3}$.

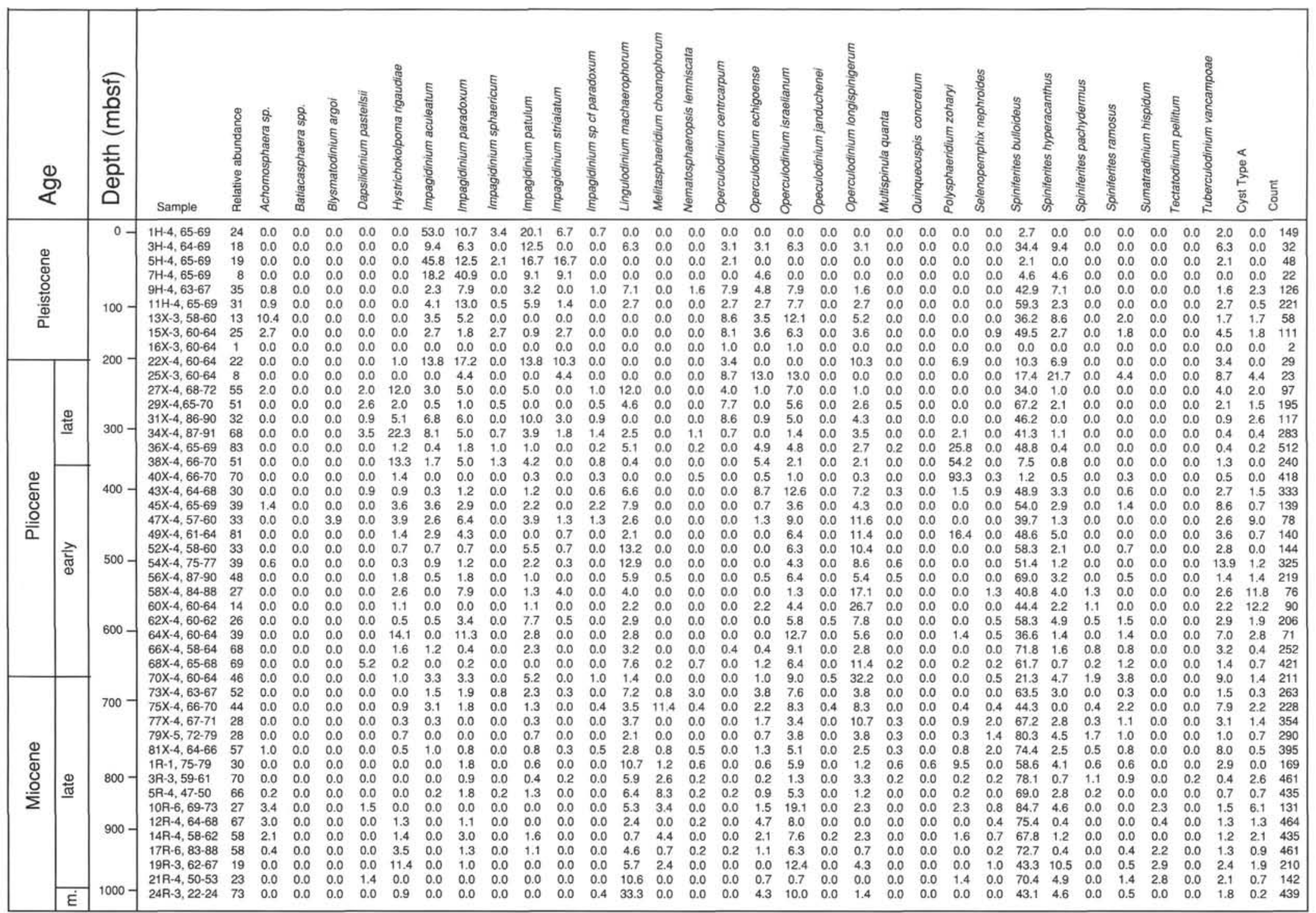


The presence of Operculodinium longispinigerum in middle Miocene through late Quaternary sections of Sites 815 and 823 and in the late Pleistocene age deposits of Site 820 (McMinn, this volume) from northeastern Australia extends the total known range of this species from the early late Miocene to early Pleistocene range previously documented at Site 765. However, this species has still not been reported from Holocene samples, surface sediment samples, or living assemblages.

With the exception of Blysmatodinium argoi, which has only previously been reported by McMinn (1992a), all of the above species have similar biostratigraphic ranges in areas outside the Australian region. These were reviewed by McMinn (1992a). The biostratigraphic ranges of these species (Fig. 2) will form the basis of a future tropical Neogene dinoflagellate cyst zonation. Other dinoflagellate cysts with consistent range tops and/or bottoms within the Neogene, such as Achomosphaera ramulifera, Spiniferites rubinus and so forth, are apparently restricted to temperate or boreal environments and were not recorded here, but are discussed elsewhere (McMinn, 1992b; Bujak and Matsuoka, 1986).

\section{COMPARISON OF ASSEMBLAGES FROM SITES 815 AND 823}

The paleogeographic settings of Sites 823 and 815 have several dissimilarities. Site 823 , located $\sim 200 \mathrm{~km}$ from shore, is currently at a depth of $1638 \mathrm{~m}$ in the central western Queensland Trough. Benthic foraminifers imply that deposition has occurred at lower bathyal paleodepths (1000-2000 m) since the late Miocene. However, Site 815 is located $\sim 250 \mathrm{~km}$ from shore, at a depth of only $450 \mathrm{~m}$ on the northern margin of the Marion Plateau. Here, benthic foraminifers indicate outer neritic water depths $(100-200 \mathrm{~m})$ during the latest Miocene, deepening to upper bathyal paleodepths (200-600 m) during the Pliocene.

Most dinoflagellates are planktonic and, therefore, their distribution in the water column is controlled not so much by the depth of water beneath them, but by factors related to availability of nutrients, turbidity, salinity, and temperature (McMinn, 1991; Wall et al., 1977). In shallow waters, particularly those shoreward of the shelf-break, bathymetry is likely to significantly effect the distribution of surface currents and upwelling zones and hence the nutrient supply. However, at oceanic sites the effects of deeper topographic features are less likely to be significant and dinoflagellate cyst distribution patterns are more likely to reflect the presence of the predominantly oligotrophic, mid-oceanic waters. Water depths above the submerged margin plateaus off the northern Queensland coast are considerably less than those of the surrounding ocean basins, but these changes in benthic topography are apparently insufficient to significantly effect either local surface currents or upwelling and consequently have not been reflected in the distribution of dinoflagellate cyst assemblages. Assemblages from Sites 815 and 823 are similar and apparently show few indications of their differing positions and bathymetric histories.

Wall et al. (1977), Harland (1983), Wrenn and Kokinus (1986) and McMinn (1992a, 1992c) have described a distinctive oceanic dinoflagellate cyst assemblage that is dominated by Impagidinium spp. and Nematosphaeropsis lemniscata. This assemblage is well represented throughout the Neogene section at Sites 815 and 823 but became significantly more abundant after the late Pliocene. McMinn (1992c) used the changing abundance of this assemblage in a Quaternary sequence from southeastern Australia to indicate changes in sea level. However, at Sites 815 and 823 , the correlation between the abundance of this assemblage and the relative dinoflagellate percentage (the proportion of dinoflagellates in a palynomorph assemblage), another factor that usually increases with distance from shore, is poor, and other data reflecting sea-level change are unavailable. Therefore, as it is not possible to independently establish the validity of the oceanic assemblage/sea-level change correlation at these sites, an interpretation in terms of sea-level change would be unwarranted.

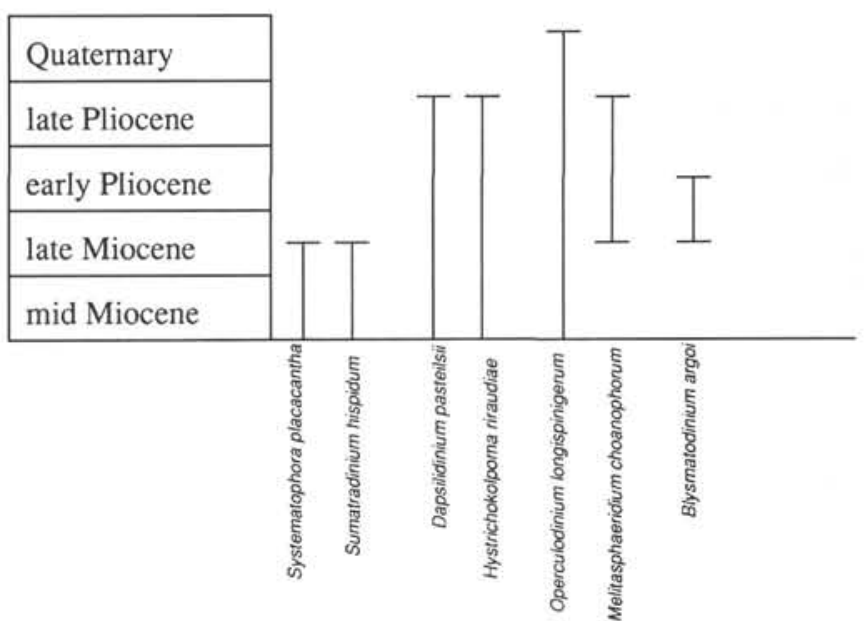

Figure 2. Distribution of selected dinoflagellate cysts that have restricted biostratigraphic ranges within the Neogene sequences of ODP Sites 765, 815. and 823 from northern Australia.

\section{COMPARISON WITH OTHER SITES}

McMinn (1992a) reviewed the composition of Neogene, tropical, and subtropical dinoflagellate cyst assemblages and compared them with those recovered from Site 765, off the northwestern coast of Australia. The assemblages documented from Sites 815 and 823 most closely resemble those from Site 765, which were also obtained from a tropical, outer-shelf, abyssal-plain environment. The most consistently abundant taxa seen were Spiniferites bulloideus and Operculodinium israelianum. Other taxa that achieve scattered dominance include Polysphaeridium zoharyi, Lingulodinium machaerophorum, Impagidinium spp., and Operculodinium longispinigerum. This composition is consistent with other tropical and subtropical locations, particularly those from deeper water settings such as the equatorial Pacific Ocean (Jarvis and Tocher 1985) and the Gulf of Mexico (Wrenn and Kokinos 1986).

\section{SYSTEMATIC PALYNOLOGY}

Division DINOPHYTA Pascher, 1914

Class DINOPHYCEAE Fritsch, 1935

Order PERIDINIALES Haeckel, 1894

Achomosphaera sp. (PI. 2, Fig. 16).

Batiacasphaera micropapillata Stover, 1977 (PI. 2, Fig. 15).

Blysmatodinium argoi McMinn, 1992 (PI. 2, Figs. 4, 5).

Dapsilidinium pasteilsii (Davey and Williams, 1966) Bujak et al., 1980 (Pl. 3 , Figs. 1, 2).

Hystrichokolpoma rigaudiae Deflandre and Cookson, 1955 (PI. 3, Fig. 8).

Impagidinium aculeatum (Wall, 1967) Lentin and Williams, 1981 (PI. 1, Figs. $1,3)$.

Impagidinium paradoxum (Wall, 1967) Stover and Evitt, 1978.

Impagidinium patulum (Wall, 1967) Stover and Evitt, 1978 (Pl. 1, Figs. 11, 14). Impagidinium sphaericum (Wall, 1967) Lentin and Williams, 1981 (Pl. 1, Figs. $2,6,9,10,13)$.

Impagidinium strialatum (Wall, 1967) Stover and Evitt, 1978 (PI. 1, Fig. 12). Impagidinium sp. cf. I. paradoxum (Wall, 1967) Stover and Evitt, 1978 (PI. 1, Figs. 3, 4, 7, 8),

Impletosphaeridium spp. (PI. 2, Fig. 10).

Lingulodinium machaerophorum (Deflandre and Cookson, 1955) Wall, 1967 (PI. 3, Fig. 3).

Melitasphaeridium choanophorum (Deflandre and Cookson, 1955) Harland and Hill, 1979 (Pl. 2, Figs. 6, 7).

Multispimula quanta Bradford, 1975 (PI. 3, Fig. 5).

Nematosphaeropsis lemniscata Bujak, 1984 emend. Wrenn, 1988. (PI. 2, Fig. 19).

Operculodinium centrocarpum (Deflandre and Cookson, 1955) Wall, 1967 (Pl. 2, Fig. 14). 
Operculodinium israelianum (Rossignol, 1962) Wall, 1967 (PI. 2, Figs. 11, 12). Operculodinium janduchenei Head et al., 1989 (PI. 2, Figs. 1, 2, 3).

Operculodinium longispinigerum Matsuoka, 1983 (PI. 2, Fig. 13).

Operculodinium echigoense Matsuoka, 1983 (PI. 2, Figs. 20, 21, 22).

Operculodinium sp. cf. O. janduchenei Head et al., 1989.

Polysphaeridium zoharyi (Rossignol, 1962) Bujak et al., 1980.

Pyxidinopsis sp. (PI. 2, Figs. 8, 9).

Quinquecuspis concretum (Reid 1977) Harland 1982.

Reticulosphaera sp.

Selenopemphix nephroides Benedek, 1972 (PI. 3, Fig. 4).

Spiniferites bulloideus (Deflandre and Cookson, 1955) Sarjeant, 1970.

Spiniferites hyperacanthus (Deflandre and Cookson, 1955) Cookson and Eisenack, 1974.

Spiniferites membranaceus (Rossignol, 1964) Sarjeant, 1970.

Spiniferites mirabilis (Rossignol, 1964) Sarjeant, 1970.

Spiniferites pachydermus (Rossignol, 1964) Sarjeant, 1970 (Pl. 2, Fig. 17).

Spiniferites ramosus (Ehrenberg, 1838) Loeblich and Loeblich, 1966 (Pl. 2, Fig. 18).

Stelladinium reidii Bradford, 1975.

Sumatradinium hispidum (Drugg, 1970) Lentin and Williams, 1976 (PI. 3, Fig. 7).

Tectatodinium pellitum Wall, 1967.

Tuberculodinium vancampoae Wall, 1967 (Pl. 3, Fig. 6).

Votadinium calvum Reid, 1977.

\section{REFERENCES*}

Bujak, J.P., and Matsuoka, K., 1986. Late Cenozoic dinoflagellate cyst zonation in the western and northern Pacific. In Wrenn, J.H., Duffield, S.L., and Stein, J.A. (Eds.), Am. Assoc. Stratigr. Palynol. Contrib. Ser., 17:7-25.

Deflandre, G., and Cookson, I.C., 1955. Fossil microplankton from Australian late Mesozoic and Tertiary sediments. Aust. J. Mar. Freshwater Res., 6:242-313.

Davies, P.J., McKenzie, J.A., Palmer-Julson, A., et al., 1991. Proc. ODP, Init. Repts., 133: College Station, TX (Ocean Drilling Program).

Duffield, S.L., and Stein, J.A., 1986. Peridiniacean-dominated dinoflagellate cyst assemblages from the Miocene of the Gulf of Mexico, off-shore Louisiana. Am. Assoc. Stratigr. Palynol. Contrib. Ser., 17:27-45.

Gamerro, J.C., and Archangelsky, S., 1981. Palinozonas Neocretacicas y Tertiarias de la plataforma continental Argentina en la Cuenca del Colorado. Rev. Esp. Micropaleontol., 13:119-140.

Harland, R., 1983. Distribution maps of Recent dinoflagellate cysts in bottom sediments from the North Atlantic Ocean and adjacent seas. Palaeontology, 26:321-387.
Head, M.J., Norris, G., and Mudie, P.J., 1989. Palynology and dinocyst stratigraphy of the Miocene in ODP Leg 105, Hole 645E, Baffin Bay. In Srivastava, S.P., Arthur, M., Clement, B., et al., Proc. ODP, Sci. Results, 105: College Station, TX (Ocean Drilling Program), 467-514.

Jarvis, I., and Tocher, B., 1985. Neogene and Quaternary dinoflagellate biostratigraphy in the eastern equatorial Pacific Ocean, Deep Sea Drilling Project Leg 85. In Mayer, L., Theyer, F., Thomas, E., et al., Init. Repts. $D S D P, 85$ : Washington (U.S. Govt. Printing Office), 407-412.

Lenoir, E.A., and Hart, G.F., 1986. Burdigalian (Early Miocene) dinocysts from offshore Louisiana. In Wrenn, J.H., Duffield, S.L., and Stein, J.A. (Eds.), Am. Assoc. Stratigr. Palynol. Contrib. Ser., 17:59-81.

Martin, H.A., 1991. Dinoflagellate and spore pollen biostratigraphy of S.A.D.M.E. MC63 bore, western Murray Basin. Alcheringa, 15:107-144 .

McMinn, A., 1992a. Neogene dinoflagellate distribution in the eastern Indian Ocean from Leg 123, Site 765. In Gradstein, F.M., Ludden, J.N., et al., Proc. ODP, Sci. Results, 123: College Station, TX (Ocean Drilling Program), 429-441.

, 1992b. Pliocene to Holocene dinoflagellate cyst biostratigraphy of the Gippsland Basin, Australia. In Head, M.J., and Wrenn, J.H. (Eds.), Neogene and Quaternary Dinoflagellate Cysts and Airtarchs. Am. Assoc. Stratigraphic Palynol. Found. (Dallas), 147-161.

, 1992c. Quaternary dinoflagellate cyst distribution on the continental shelf and slope of southeastern Australia. Palynology, 16:13-24.

Truswell, E.M., Sluiter, I.R., and Harris, W.K., 1985. Palynology of the Oligocene-Miocene sequence in the Oakvale-1 corehole, western Murray Basin, South Australia. BMR. J. Aust. Geol. Geophys., 9:267-295.

Wall, D., Dale, B., Lohmann, G.P., and Smith, W.K., 1977. The environmental and climatic distribution of dinoflagellate cysts in modern marine sediments from regions in the North and South Atlantic Oceans and adjacent seas. Mar. Micropaleontol., 2:121-200.

Wrenn, J.H., and Kokinos, J.P., 1986. Preliminary comments on Miocene through Pleistocene dinoflagellate cysts from De Soto Canyon, Gulf of Mexico. In Wrenn, J.H., Duffield, S.L., and Stein, J.A. (Eds.), Am. Assoc. Stratigr. Palynol. Contrib. Ser., 17:169-225.

Abbreviations for names of organizations and publication titles in ODP reference lists
follow the style given in Chemical Abstracts Service Source Index (published by American Chemical Society).

Date of initial receipt: 20 April 1992

Date of acceptance: 19 November 1992

Ms 133SR-219 

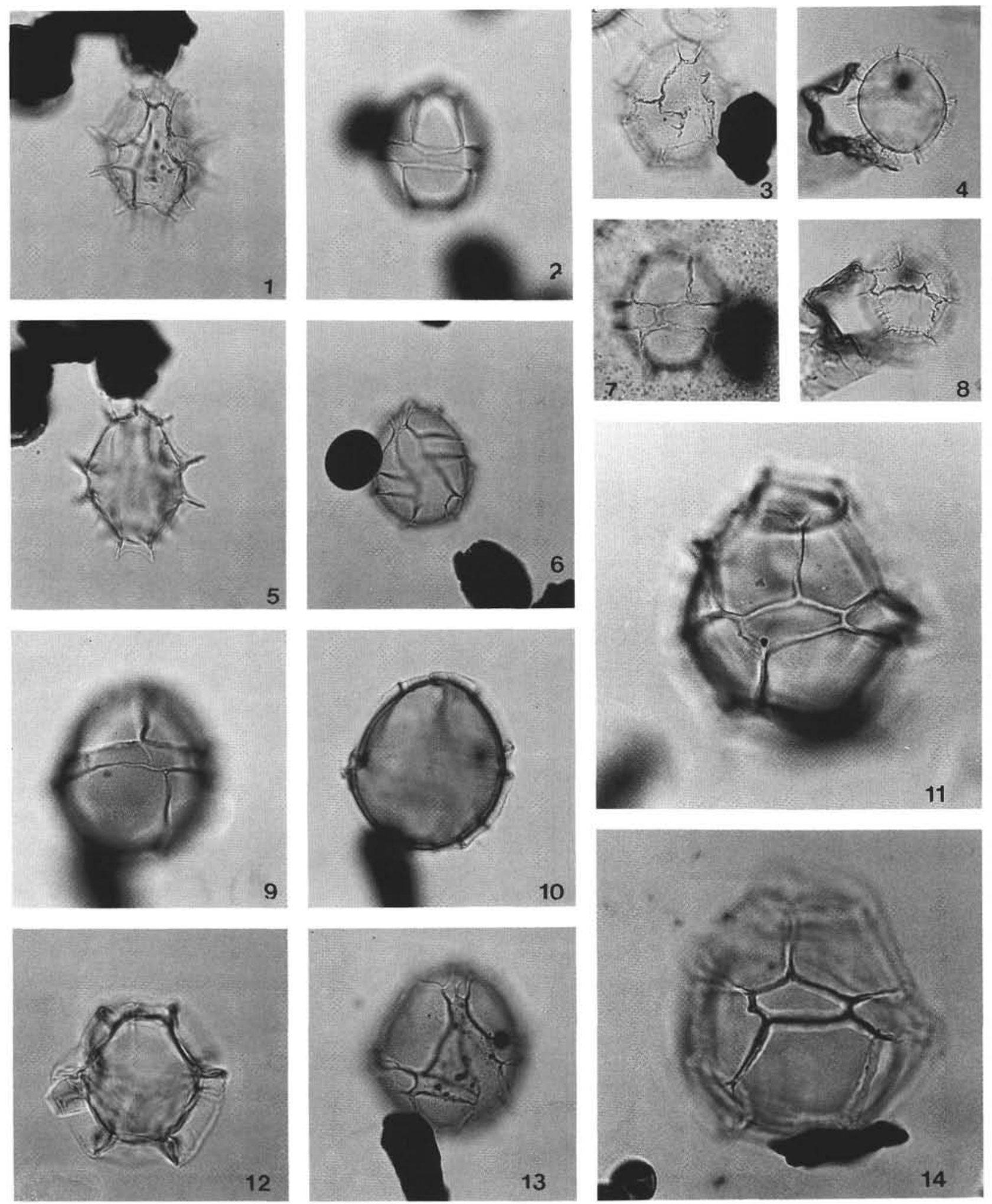

Plate 1. (All magnifications $\times 650$.) 1,5. Impagidinium aculeatum, Sample 133-815B-26X-3,98-103 cm. 2,6. Impagidinium sphaericum, Sample 133-815A-14H-3, 100-105 cm. 3, 7. Impagidinium sp. cf. paradoxum, Sample 133-815A-6H-3, 105-109 cm. 4, 8. Impagidinium sp. cf. paradoxum, Sample 133-815B-23H-3, 98-104 cm. 9, 10, 13. Impagidinium sphaericum, Sample 133-815A-14H-3, 100-105 cm. 11, 14. Impagidinium patulum, Sample 133-815B-44X-3, 105-110 cm. 12. Impagidinium strialatum, Sample 133-815B-44X-3, 105-110 cm. 

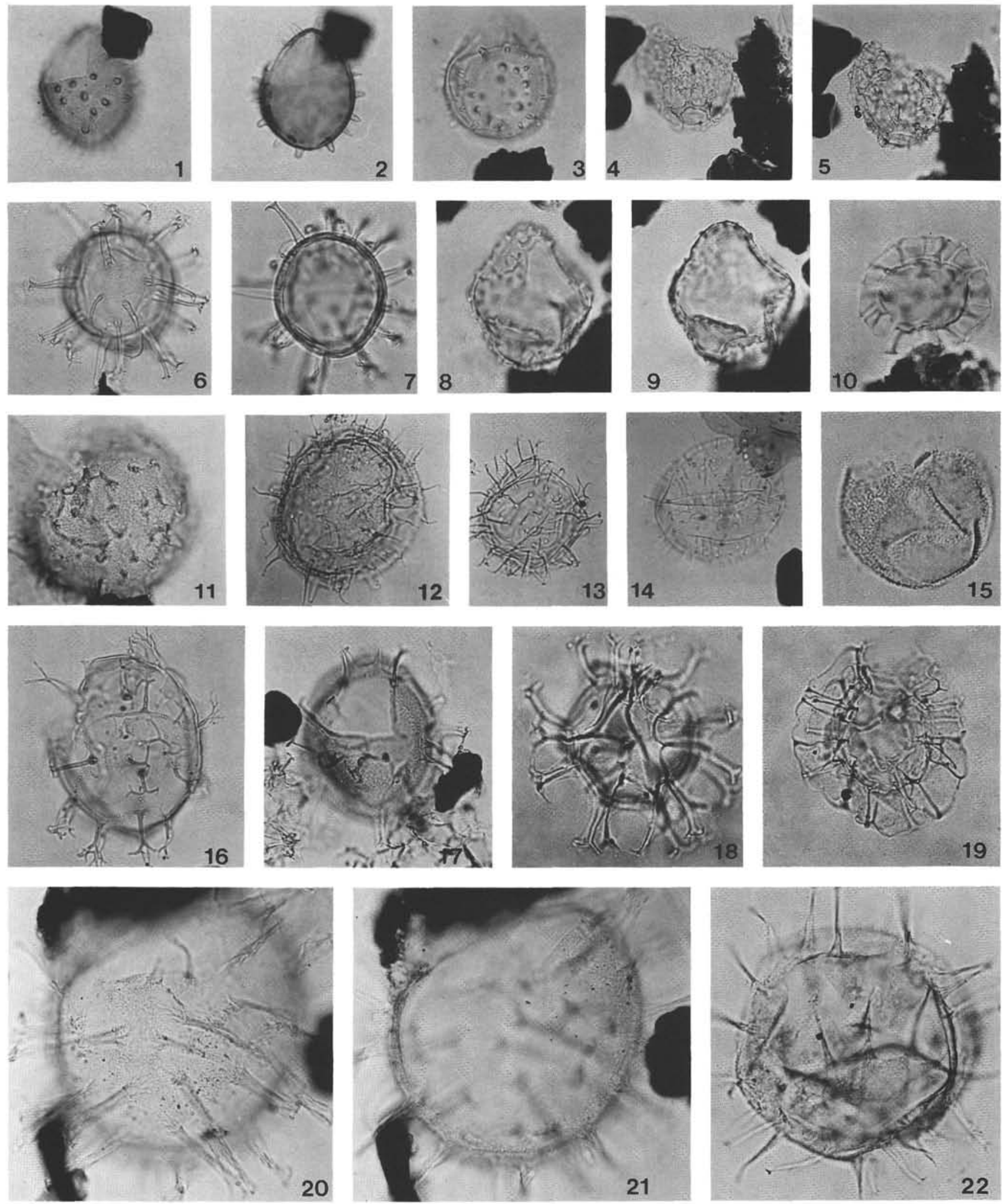

Plate 2. (All magnifications $\times 650$.) 1, 2. Operculodinium janduchenei, Sample 133-815B-26X-3, 98-103 cm. 3. Operculodinium janduchenei, Sample 133-815A-22X-3, 98-102 cm. 4, 5. Blysmatodinium argoi, Sample 133-815B-27X-3, 98-102 cm. 6, 7. Melitasphaeridium choanophorum, Sample 133-815B-44X-3, 105-110 cm. 8,9. Pyxidinopsis sp., Sample 133-815B-44X-3, 105-110 cm. 10. Reticulosphaera sp., Sample 133-815B-47X-3, 100-103 $\mathrm{cm} . \quad$ 11, 12. Operculodinium israelianum, Sample 133-815B-27X-3,98-102 cm. 13. Operculodinium longispinigerum, Sample 133-815B-31X-3, 98-102 $\mathrm{cm}$. 14. Operculodinium centrocarpum, Sample 133-815B-31X-3, 98-102 cm. 15. Batiacasphaera sp., Sample 133-815B-47X-3, $100-103 \mathrm{~cm} .16$. Achomosphaera sp., Sample 133-815B-28X-3,98-102 cm. 17. Spiniferites pachydermus, Sample 133-815A-23H-3,98-104 cm. 18. Spiniferites ramosus. Sample 133-815B-47X-3, 100-103 cm. 19. Nematosphaeropsis lemniscata, Sample 133-815B-28X-3, 98-102 cm. 20, 21. Operculodinium echigoense, Sample 133-815A-14H-3, 100-105 cm. 22. Operculodinium echigoense, Sample 133-815B-47X-3, 100-103 cm. 

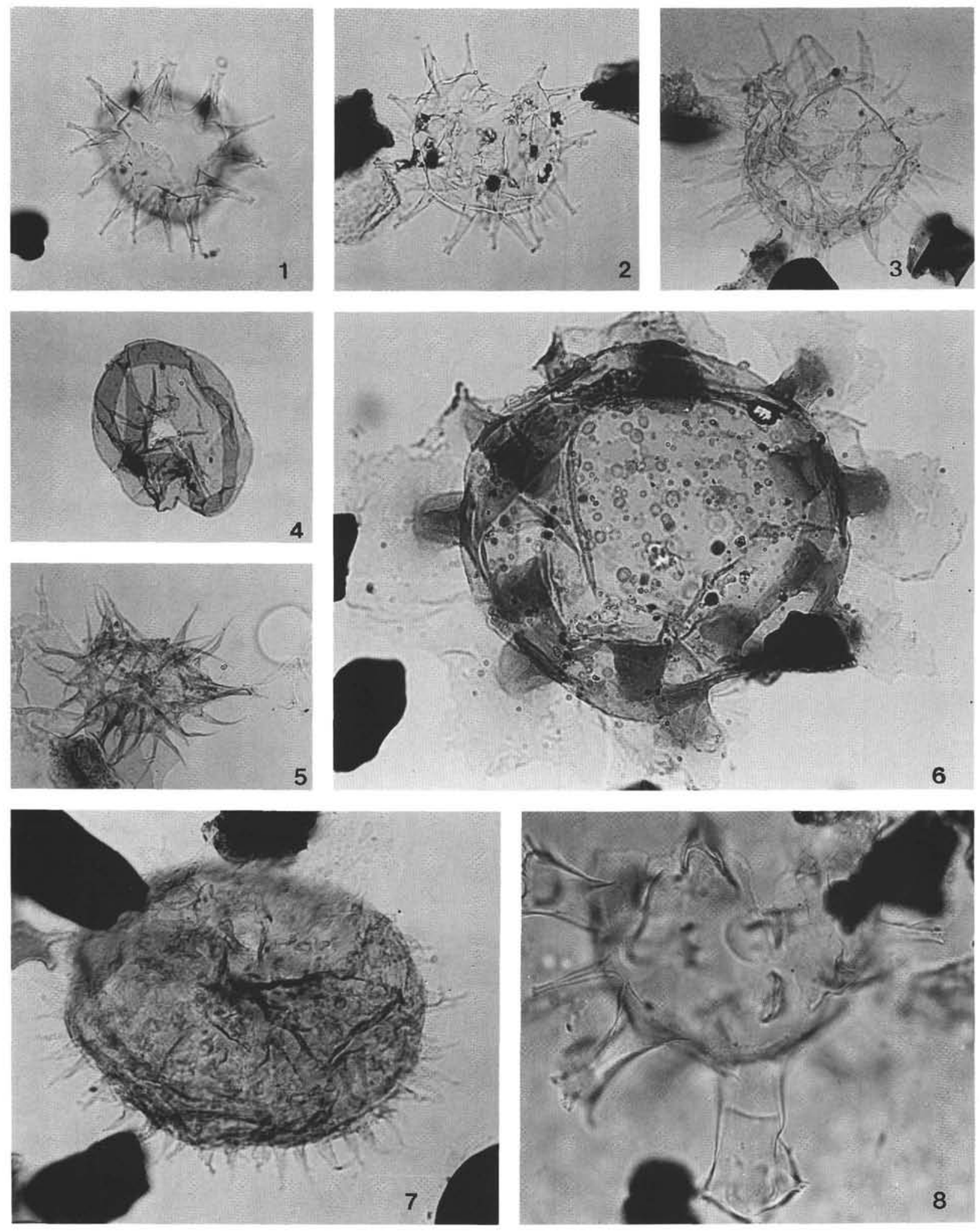

Plate 3. (All magnifications $\times 650$ ) 1. Dapsilidinium pasteilsii, Sample $133-815 \mathrm{~A}-21 \mathrm{H}-3,96-100 \mathrm{~cm}$. 2. Dapsilidinium pasteilsii, Sample 133-815A-10H-3, 60-65 cm. 3. Lingulodinium machaerophorum, Sample 133-815A-27X-3, 98-102 cm. 4. Selenopemphix nephroides, Sample 133-815B-28X-3, 98-102 cm. 5. Multispinula quanta, Sample 133-815A-13H-3, 100-105 cm. 6. Tuberculodinium vancampoae, Sample 133$815 \mathrm{~A}-19 \mathrm{H}-3,100-104 \mathrm{~cm}$. 7. Sumatradinium hispidum, Sample 133-815B-47X-3, 100-103 cm. 8. Hystrichokolpoma rigaudiae, Sample 133$815 \mathrm{~B}-47 \mathrm{X}-3,100-103 \mathrm{~cm}$. 